UDC 004:37.091.33-027.22:811.111

DOI https://doi.org/10.24919/2308-4863/42-3-7

\author{
Svitlana HOLOVINA, \\ orcid.org/0000 -0003-1455-0647 \\ English teacher \\ Maritime Applied College of Kherson State Maritime Academy \\ (Kherson,Ukraine) goooolvin@gmail.com
}

\title{
THE EFFECTIVENESS OF USING PADLET FOR TEACHING ENGLISH
}

Modern teaching process doesn't exist without different digital tools. The article describes Padlet, which is mostly known as a digital bulletin board and it's one of the best and most convenient websites designed for digital learning. This interactive tool is easy to use and easily accessible from nearly any web browser-capable device, so it's a great resource for teachers and students. This notice board allows users to share different kinds of content such as images, links, videos, audios and documents, all posted on a wall. It is a good collaborative tool (allows users to collaborate in many different ways), it is also a nice tool for peer feedback, as students can read or listen to each other and provide feedback in the form of a comment and, moreover, it supports active blended learning. This article focuses on numerous advantages of a digital bulletin board Padlet, such as the possibility of tracking learning, sharing materials with each other, creating various content, free and easy access to the website, active supporting teaching and learning, the possibility to control the content, applying to different language levels of students, enabling efficient collaboration, storage of different kind of information. One of the greatest appeals of Padlet for classroom use is the fact that many people can post to the same board at the same time. Also, linked documents can be uploaded and viewed within Padlet, users don't have to download them, so Padlet is an ideal platform for students to share their work with teachers and peers The article also highlights activities which can be done with the help of this website and how they can be used for teaching and learning English. From a brainstorming board to a live questions bank, there are lots of ways to use Padlet, limited only by teacher and students' imagination.

Key words: Padlet, notice board, bulletin board, digital tool.

Свімлана ГОЛОВІНА, orcid.org/0000 -0003-1455-0647 викладач англійської мови

Морського фахового коледжу

Херсонської державної морської академії (Херсон, Україна) goooolvin@gmail.com

\section{ЕФЕКТИВНІСТЬ ВИКОРИСТАННЯ РАDLЕТ ДЛЯ НАВЧАННЯ АНГЛІЙСЬКОЇ МОВИ}

Сучасний навчальний прочес не існує без різних ичиррових інструментів. У статті описано Padlet, який відомий переважно як ичифрова дошка оголошень, це один із найкращих та найзручніших вебсайтів, призначених для цифрового навчання. Цей інтерактивний інструмент простий у використанні та легкодоступний практично з будь-якого пристрою з підтримкою веббраузера, тому він є чудовим ресурсом для викладачів та студентів. Ця ицфррова дошка оголошень дозволяе користувачам обмінюватися різними видами контенту, я-от: зображення, посилання, відео, аудіо та документи, усі розміщені на стіні. Це хороший інструмент для співпраці (дозволяє користувачам співпраџювати різними способами), він також є чудовим інструментом для здійснення зворотного зв 'язку з однолітками, оскільки студенти можуть читати або слухати один одного та надавати зворотний зв'язок у вигляді коментаря, крім того, він підтримує активне змішане навчання.

Ця стаття присвячена численним перевагам цифрової дошки оголошень Padlet, серед яких можливість відстежування навчання, обмін матеріалами один з одним, створення різноманітного контенту, безкоштовний та простий доступ до вебсайту, активна підтримка викладання та навчання, можливість контролю змісту, застосування до різних мовних рівнів студентів, забезпечення ефективної співпраці, зберігання різного роду інформаиії. Одна з найбільших переваг Padlet для використання у класі - ие той факт, щзо багато людей можуть водночас писати повідомлення на одній дошиі. Окрім того, пов'язані документи можна завантажувати та переглядати у програмі Padlet, користувачам не потрібно їх завантажувати на свій пристрій, тому Раdlet $\epsilon$ ідеальною платформою для студентів, щзоб поділитися своєю роботою з викладачами й однолітками. У статті також висвітлюються види діяльності, які можна проводити за допомогою иьього вебсайту, та те, як їх можна використовувати для навчання та вивчення англійської мови. Від мозкового штурму до банку запитань - у реальному часі існує безліч способів використання Padlet, обмежених лише уявою викладача та студентів.

Ключові слова: Padlet, дошка оголочень, інформаційний бюлетень, ицифровий інструмент. 
Problem statement. Education has changed dramatically recently - the world turned to digitalized learning, especially since the Covid-19 pandemic which affected the process of knowledge acquisition all over the world. Although interest in digital education had increased greatly before the virus, the pandemic boosted its adoption. Different educational institutions around the world were forced to close their doors to prevent the spread of the disease, so online learning became an urgent necessity, rather than an option. Educators had to familiarize themselves with a range of online platforms and digital tools in order to implement online learning. Online notice board Padlet is one of easy-to-use tools that can help digitize the classroom and can be used both by students and by teachers.

Recent research and publication. Digital learning was investigated by many scientists. The use of notice board Padlet was described by B. Fuchs in a scientific article called "The Writing on the Wall Using Padlet for Whole-Class Engagement" (Fuchs, 2014: 7). In this work the author states that Padlet provides a free, multimedia-friendly wall which can be used to encourage real-time, whole-class participation and assessment. The researcher reviews barriers to participation, risks and benefits of real-time participatory technology in class and shares her experience of using Padlet. Another research on this tool was done by A. Weller (Weller, 2013). This research explores the use of Web 2.0 in pre-service teachers' professional learning. The researcher states that usage of the digital tool Padlet has some advantages, such as the advantage of permanence and the advantage of introducing students to a new and fun technology. A. R. Deni and Z. I. Zainal also conducted some studies focusing on the use of Padlet for improving communication skills. They conducted the survey which showed that the use of Padlet supported students' learning as it helped enhance learner engagement with the subject (Deni, Zainal, 2015). Researchers M. Haris, M. M. Yanus, J. H. Badusah investigated the effectiveness of Padlet while learning grammar in ESL classroom in their research article; they collected data by means of pre-post tests and questionnaire survey (Haris et al., 2017). The survey showed high preference and students' positive attitude towards using Padlet for learning grammar.

The purpose of the article. This article aims to investigate using digital notice board Padlet for teaching English.

Main text. Padlet is a platform where virtual walls can be created and it can be defined in different ways: as a "digital notice board", an "online bulletin board", an "online post-it board", a "virtual wall, a "dashboard" etc. But, first of all, it is a tool that can help digitize the classroom, and it offers teachers and students a great platform for learning. This digital notice board can feature images, links, videos, and documents, all posted on a wall that can be made public or private. It means that not only teacher but also students can actively participate in creating "padlets". This interactive tool is easy to use and easily accessible from nearly any web browser-capable device, so it's a great resource for teachers and students. Teachers, as well as students, can post a variety of materials: videos, images, documents and audio, presentations. Padlet is a good collaborative tool that supports active blended learning.

Using Padlet has a lot of advantages:

- Social interaction. Padlet allows both synchronous or asynchronous collaboration. Students can share ideas, different materials, audio and video; they can also comment on them. The communication between a teacher and students takes place in a forum style format (learners can discuss a topic as they might on social media);

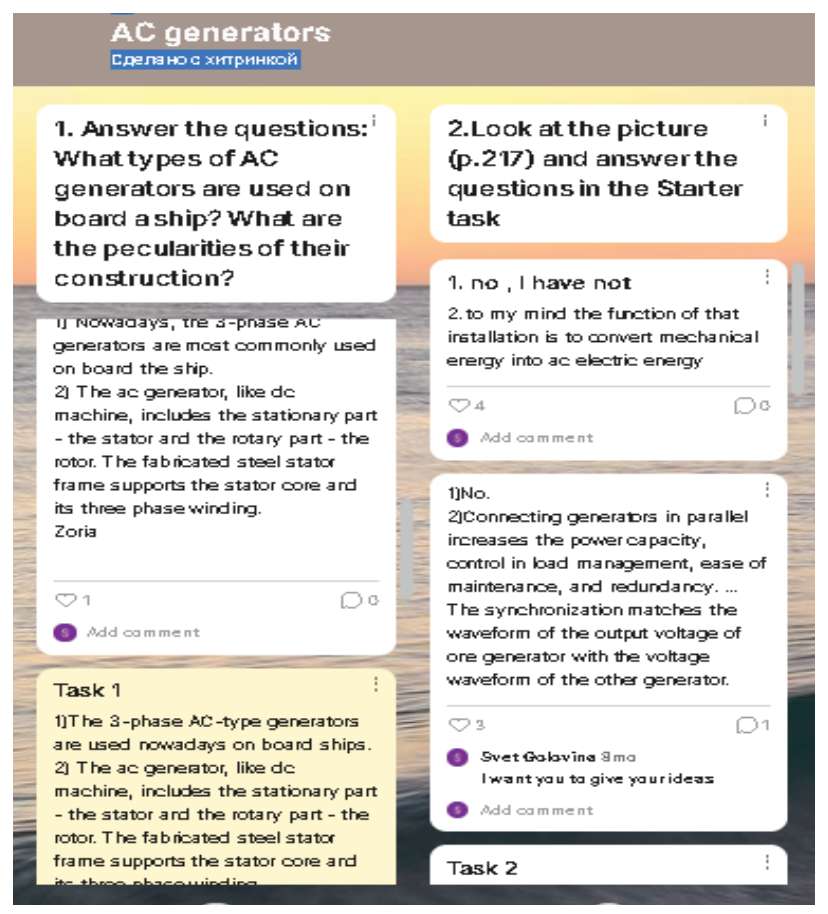

Pic. 1

- The possibility to track learning. Padlet doesn't track learning itself but it allows teachers to monitor the understanding or use of English of all learners in the class. For example, a teacher asks the students to answer the questions and they share the answers with each other. The teacher can observe who leaves the answers on the board and if they are correct or not. There is a risk that students could just copy the infor- 
mation from the Internet, that's why it's a problem to assess such answers, but the teacher can see who participates in the lesson and how the students interact with each other. If learners, for instance, record audio or write a short text, the teacher can assess their use of English and provide feedback. Padlet is also a nice tool for peer feedback, as students can read or listen to each other and provide feedback in the form of a comment;

- Sharing. Padlet doesn't provide the content (learning materials) for teachers or learners but it provides the opportunity for teachers to share content in the form of links (to videos, sites etc.). It also allows students to share content created by them in the form of text posts, videos, recorded audios, Power Point presentations or documents. It's great for project work, as learners can go away and research something, after that report back on a Padlet;

- Language level and skills. Digital board Padlet can be applied with any level of learner. Skills that students develop depend on the task they perform. Learners can develop writing skills (e.g. write a short review of the film you watched) or speaking skills (record yourself expressing opinion about air pollution). Before listening or reading, students can brainstorm vocabulary related to a topic to activate existing knowledge;

- Various content. Both teachers and students can post text, images, videos, files, links, presentations (almost any kind of digital material). Learners can see what is posted by their groupmates and by the teacher, as well as comment or vote on the posts if the board owner allows. One of the tremendous advantages of Padlet for classroom use is the that many people can post to the same board at the same time, encouraging collaborative work;

- Variety of Padlet designs. A teacher has freedom in creating different designs for the lessons: Wall, Stream, Grid, Shelf, Map, Canvas, Timeline. For example, if you want a brick-like layout of the material, you select "Wall" design, if you give preference to a series of columns, you select "Shelf" design;

- Learner-generated content. Using student-generated content makes learning more meaningful and personalised. Instead of using coursebook texts, images and activities, Padlet can help you encourage students to design activities themselves. This requires a lot of support and feedback from the teacher while students are producing the material to be used in class;

- Easily accessible. One more significant advantage of Padlet is that it is accessible from nearly any web browser-capable device (a smartphone, a tablet, a laptop or a desktop computer). Access to this noticeboard is provided via a website or app, all a teacher needs to do is to give a unique link to the students;
- Supporting teaching and learning. Padlet is a digital tool which gives learners many advantages. For example, they can receive feedback on their work, look back at previous work to identify progress. For teachers, this noticeboard helps assess the learning of everyone in the class;

- Control over content. Teacher has control over the content, design, layout and privacy of the walls. The creator of a wall can also decide who has access to the walls by making changes to the privacy setting. Teachers can make the walls exclusive (by giving visitors the QR code, the links and/or passwords to the walls) or they make the walls public. The links to the walls can be personalised. The creator can also determine what visitors can do on the wall, whether to allow visitors, for example, to only read what is on the wall or to write on the wall and edit their own posts. The creator can also moderate posts before letting others view them;

- Collaboration. Users can collaborate in many different ways. For example, students can do a single task together, for example, each of them should add one word to the list or write one idea;

- Convenient storage place. Linked documents can be uploaded and viewed within Padlet, users don't have to download them, so Padlet is an ideal platform for students to share their work with teachers and peers ( $250 \mathrm{mb}$ storage per item upload limit).

An online bulletin board can be used in many different ways, everything depends on a teacher's imagination and experience. Here are some ideas for using Padlet during a lesson.

1. Predicting activity. Ask your students to predict what will happen next by posting notes on a Padlet. Later, refer to those notes to see how close students' predictions were.

2. Brainstorming. Let your students brainstorm the words on the topic they are going to learn. For example, learners brainstorm the topic of Healthy lifestyle by writing all the words they associate with it on the digital board. Share the board and let everybody share their ideas and comments. Padlet allows every student to see what others think. You can discuss some of the answers with the whole class.

3. Class document hub. Teacher can upload important class files to Padlet and students can go there to download them any time, so it can be used as a storage board.

4. Answering questions. Students can attach answers to questions or ideas under the box with the task. The answers can be in any format - text, audio, video.

5. Interactive storytelling. Create a story and ask learners where it should go next. They can type their ideas into the Padlet. 


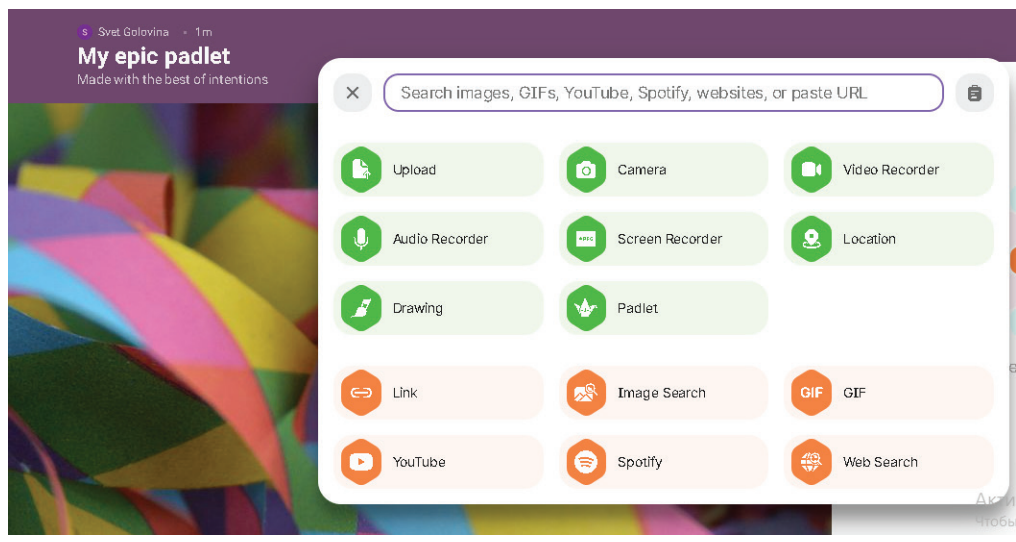

Pic. 2

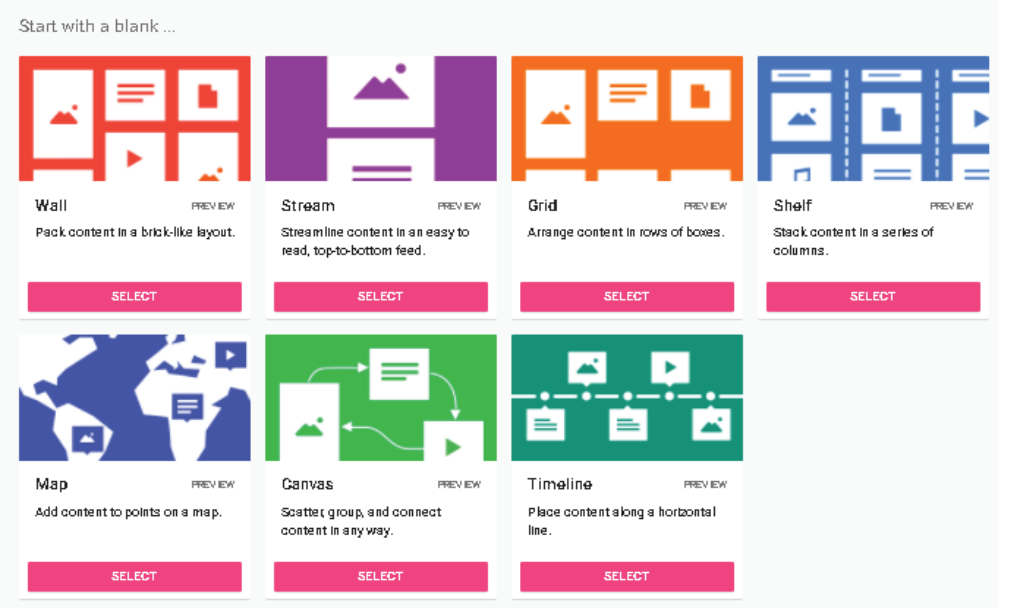

Pic. 3

6. Gathering students' works. Learners' work can be gathered all in one place but it should be noted that ordinary homework is inappropriate, because others can see what each of them has done. It should be used for more creative tasks or for research work. When you let your students do some research, for instance, on "Environmental problems", you have all the articles and research collected at the same place. Other students can take a look at the research of someone else as well.

7. Using Padlet as an icebreaker or warmer activity at the beginning of the lesson. For example, let students play "Two truths and one lie" game.

8. Creating lists. This platform allows students to make different lists. For example, the task is to make the list of necessary items for travelling and the students either make up the lists of 5-10 things individually and then they post these lists and can look through their groupmates' lists and see which items coincide and which are different.

9. Discussion. Padlet can be also used for discussion tasks. For example, a teacher gives the task to discuss the statement and the students write their ideas on the digital board below the statement or record audios (videos).

10. Tops and tips. Use Padlet to conduct peer assessment and feedback. Let students add two "tops" and one "tip" on the wall of their fellow student who has just finished his presentation. "Tops" are things the student did well and a "tip" could be something the student should improve the next time.

Noticeboard Padlet can be used either for the part of the lesson or for the whole lesson but if it is used for the whole lesson, a teacher should plan all activities thoroughly.

Conclusion. A digital bulletin board (Padlet) is a powerful and easy-to-use tool that which can be used to encourage real-time, whole-class participation and assessment. This notice board can feature images, links, videos, audios, presentations, and documents, all posted on a wall. Also, not only teacher but also students can actively participate in creating a virtual wall. Using Padlet has a lot of advantages such as: 
supporting teaching and learning, control over the content, it is easily accessible, various content can be posted, it can be used for different levels and can develop different skills etc. Moreover, Padlet can be utilized for a wide range of different activities such as discussion, creating lists, brainstorming, gathering students' works and many others. In conclusion, since the interactive space is easy to use and easily accessible from nearly any web browser-capable device, it's a great resource for teachers and students.

\section{BIBLIOGRAPHY}

1. Best J. W., Kahn J. W. Research in education. Boston : Allyn \& Bacon, 2002. 498 p.

2. Biggs J., Tang K. Teaching for quality learning at University. Maidenhead : Oxford University Press, 2011. 357 p.

3. Bower M. A typology of Web 2.0 learning technologies. URL: http://www.educause.edu/library/resources/typologyweb-20-learning-technologies (Last accessed: 01.09.2021).

4. Dembo S. E., Bellow A. S. Untangling the Web: 20 Tools to Power Up Your Teaching. London : SAGE Publications, 2013. 200 p.

5. Deni A., Zainal Z. I. Let's write on the Wall: Virtual Collaborative Learning Using Padlet. URL: https://www.researchgate.net/publication/291972839_Let's_Write_On_The_Wall_Virtual_Collaborative_Learning_Using Padlet (Last accessed: 01.09.2021).

6. Edwards L. What is Padlet and How Does It Work for Teachers and Students? URL: https://www.techlearning.com/ how-to/what-is-padlet-and-how-does-it-work-for-teachers-and-students (Last accessed: 01.09.2021).

7. Fuchs B. The writing is on the wall: using Padlet for whole-class engagement. URL: https://uknowledge.uky.edu/cgi/ viewcontent.cgi? article $=1241 \&$ context=libraries_facpub ( Last accessed: 01.09.2021).

8. Haris M., Yunus M. M., Badusah J. H. The Effectiveness of Using Padlet in ESL Classroom. URL: https://www.researchgate.net/publication/314103688_THE_EFFECTIVENESS_OF_USING_PADLET_IN_ESL_ CLASSROOM (Last accessed: 01.09.2021).

9. Lankshear V., Knobel M. New Literacies: Everyday Practices and Classroom Learning. Maindenhead: Open University Press, 2006. 272 p.

10. Renard L. 30 creative ways to use Padlet for teachers and students. URL: https://ditchthattextbook.com/20-usefulways-to-use-padlet-in-class-now/ (Last accessed: 01.09.2021).

11. Warwick L. An excellent collaboration tool for teachers and learners. URL: https://thedigitalteacher.com/reviews/ padlet (Last accessed: 01.09.2021).

12. Weller A. The use of Web 2.0 technology for pre-service teacher learning in science education. URL: https://www.researchgate.net/publication/318395036_The_use_of_Web_20_technology_for_pre-service_teacher_learning in_science_education (Last accessed: 01.09.2021).

\section{REFERENCES}

1. Best J. W., Kahn J. W. Research in education. Boston : Allyn \& Bacon, 2002. 498 p.

2. Biggs J., Tang K. Teaching for quality learning at University. Maidenhead : Oxford University Press, 2011. 357 p.

3. Bower M. A typology of Web 2.0 learning technologies. URL: http://www.educause.edu/library/resources/typologyweb-20-learning-technologies (Last accessed: 01.09.2021).

4. Dembo S. E., Bellow A. S. Untangling the Web: 20 Tools to Power Up Your Teaching. London: SAGE Publications, 2013. 200 p.

5. Deni A., Zainal Z. I. Let's write on the Wall: Virtual Collaborative Learning Using Padlet. URL: https://www.researchgate.net/publication/291972839_Let's_Write_On_The_Wall_Virtual_Collaborative_Learning_Using_ Padlet (Last accessed: 01.09.2021).

6. Edwards L. What is Padlet and How Does It Work for Teachers and Students? URL: https://www.techlearning.com/ how-to/what-is-padlet-and-how-does-it-work-for-teachers-and-students (Last accessed: 01.09.2021).

7. Fuchs B. The writing is on the wall: using Padlet for whole-class engagement. URL: https://uknowledge.uky.edu/cgi/ viewcontent.cgi?article $=1241 \&$ context=libraries_facpub ( Last accessed: 01.09.2021).

8. Haris M., Yunus M. M., Badusah J. H. The Effectiveness of Using Padlet in ESL Classroom. URL: https://www.researchgate.net/publication/314103688_THE_EFFECTIVENESS_OF_USING_PADLET_IN_ESL_ CLASSROOM (Last accessed: 01.09.2021).

9. Lankshear V., Knobel M. New Literacies: Everyday Practices and Classroom Learning. Maindenhead : Open University Press, 2006. 272 p.

10. Renard L. 30 creative ways to use Padlet for teachers and students. URL: https://ditchthattextbook.com/20-usefulways-to-use-padlet-in-class-now/ (Last accessed: 01.09.2021).

11. Warwick L. An excellent collaboration tool for teachers and learners. URL: https://thedigitalteacher.com/reviews/ padlet (Last accessed: 01.09.2021).

12. Weller A. The use of Web 2.0 technology for pre-service teacher learning in science education. URL: https://www.researchgate.net/publication/318395036_The_use_of_Web_20_technology_for_pre-service_teacher_learning in_science_education (Last accessed: 01.09.2021). 